\title{
Fatores que interferem na qualidade do DNA extraído de amostras biológicas armazenadas em blocos de parafina
}

Primeira submissão em 19/01/11 Última submissão em 20/07/11 Aceito para publicação em 26/07/11 Publicado em 20/10/11

\author{
Factors that affect the quality of DNA extracted from biological samples stored in paraffin blocks \\ Anderson Paulo Scorsato'; José Ederaldo Queiroz Telles²
}

\begin{tabular}{l|l}
\multicolumn{1}{c|}{ unitermos } & resumo \\
\hline Tecido & Os avanços tecnológicos e metodológicos da biologia molecular criaram a possibilidade de obter \\
Parafina & DNA de amostras teciduais estocadas em blocos de parafina, alternativa esta que permite estudos \\
DNA & retrospectivos de grandes bancos de tecidos contendo inúmeras doenças raras. O objetivo deste trabalho \\
foi a realização de uma breve revisão de alguns fatores inerentes à qualidade do produto extraído & proveniente de blocos de parafina armazenados. Os processos envolvidos nas fases de prefixação, fixação, \\
Formol & pós-fixação apresentam aspectos que são causa de resultados de produtos finais insatisfatórios. Na fase \\
Qualidade & de prefixação, alterações bioquímicas influenciam na preservação das macromoléculas. As mudanças \\
& moleculares causadas pelos fixadores para evitar autólise celular podem ser um limitante no momento \\
& da extração de DNA. A qualidade do DNA obtido nas duas primeiras fases é considerada importante \\
& para os procedimentos de pós-fixação (extração e purificação do DNA). Existem na literatura vários \\
& protocolos, com diferentes passos que podem ser modificados, para a obtenção de DNA de material \\
& parafinado. Assim, a compreensão das reações em cada fase é importante para solucionar ou minimizar \\
& problemas, que influenciam na qualidade das macromoléculas de DNA.
\end{tabular}

\section{abstract}

Technological and methodological advances in molecular biology have enabled the obtainment of DNA from paraffin embedded tissue, thus allowing the use of extensive pathological archive sources and samples of uncommon diseases in retrospective studies. The aim of this work was to carry out a brief review of some factors inherent in the quality of product from paraffin embedded material. The processes involved in the pre-fixation, fixation and post-fixation phases have several aspects that may result in unsatisfactory final products. In the pre-fixation phase, biochemical changes influence the preservation of macromolecules. The molecular changes caused by fixation, an attempt to prevent cell autolysis, may be a limiting factor at the time of DNA extraction. The quality of DNA obtained in the first two phases is regarded important for post-fixation procedures (DNA extraction and purification). In the literature there are several protocols whose steps can be modified to obtain DNA from paraffin embedded material. Therefore, the understanding of reactions at each stage is important in order to solve or minimize problems that interfere in the quality of DNA macromolecules.

\section{key words}

Tissue

Paraffin

DNA

Formal

Quality 


\section{Introdução}

Os avanços tecnológicos e metodológicos dos últimos tempos ampliaram a utilização dos blocos de parafina. $\mathrm{O}$ que inicialmente era apenas fonte de estudos histomorfológicos passou a ganhar a atenção de pesquisadores da área de biologia molecular. A evolução do diagnóstico molecular faz com que esse tipo de material seja requisitado como fonte de estudo. A obtenção de macromoléculas de amostras biológicas incluídas em parafina possibilita estudos de genes terapêuticos e estudos retrospectivos de inúmeras doenças. A partir dos testes de patologia molecular, valiosas informações clínicas são adquiridas.

A utilização dos blocos de parafina para análises moleculares têm alguns empecilhos decorrentes do processamento do material. O tempo de prefixação, fixação e, em alguns casos, descalcificação influencia diretamente na quantidade e na qualidade do DNA. Os processamentos histológicos causam alterações significativas na estrutura e na constituição do DNA, as quais também atuam de forma negativa nos passos subsequentes à extração, como, por exemplo, na espectrofotometria e na reação em cadeia pela polimerase $(\mathrm{PCR})^{(5,11,13,24,34)}$.

A compreensão dos fatores que estão envolvidos direta ou indiretamente no processo de extração de macromoléculas é fundamental para o resultado final do processo. A concepção de fatores, como tipo de fixador, utilização (ou não) de descalcificadores e tipo de tecido, é um dos aspectos que vai influenciar a extração. Essa compreensão é importante na definição de qual método de extração será utilizado. Existem na literatura vários protocolos para a extração de DNA a partir de material parafinado. O método mais frequentemente utilizado na extração a partir dos blocos de parafina é o de digestão enzimática proteolítica, seguido do de purificação com solvente orgânico e precipitação com etanol ${ }^{(3,24,38)}$. O objetivo deste trabalho foi fazer uma breve revisão de alguns fatores que serão importantes para a qualidade do produto extraído de amostras biológicas incluídas em parafina.

\section{Revisão}

\section{Arquivos de material biológico}

As blocotecas dos setores de patologia, primeiro banco estruturado de tecidos patológicos estabelecido em grande escala, foram e continuarão sendo valiosas fontes de pesquisa de doenças ${ }^{(23,46)}$. Todos os dias, amostras de biópsias do corpo humano são retiradas para análises diagnósticas de doenças, sendo as amostras estocadas nos laboratórios de setores de patologia. Os avanços tecnológicos e metodológicos dos últimos tempos ampliaram a utilização dos blocos de parafina; além do uso em estudos histomorfológicos, histoquímicos e imuno-histoquímicos, passaram a ser também fonte de material para a pesquisa com métodos da biologia molecular ${ }^{(5,11,38)}$.

Fatores genéticos são inerentes a muitas doenças, cuja expressão clínica resulta da combinação do efeito de genes em maior ou menor grau com o efeito do meio ambiente ${ }^{(45)}$. Esses fatores fazem que ocorra grande interesse nos estudos das bases genéticas das doenças, e os acervos de materiais biológicos que foram enviados para exame nas rotinas hospitalares permanecem como fonte de material para diferentes estudos genéticos ${ }^{(34)}$. As amostras dos blocos de parafina podem ser fontes de estudos para a epidemiologia molecular, de caráter retrospectivo, de instabilidades em regiões de microssatélites, de detecção ou diferenciação de microrganismos patogênicos ${ }^{(3,31,34,39)}$. As técnicas de biologia molecular oferecem hoje várias ferramentas para diagnóstico, monitoramento, prognóstico e decisões terapêuticas para doenças como o câncer ${ }^{(10,36)}$.

A análise molecular de ácidos nucleicos tem tradicionalmente exigido DNA genômico obtido a partir de tecidos frescos ou congelados; as macromoléculas encontram-se bem preservadas quando extraídas desse tipo de material(32,44). Embora o DNA extraído de amostras frescas ou congeladas seja o ideal para análises moleculares, nem sempre é possível congelar e/ou obter essas amostras a fresco, quando consideradas as limitações da prática clínica. Os tecidos congelados ou frescos também apresentam limitações para a avaliação histomorfológica, assim como estão tecnicamente impedidos de sua utilização para estudos retrospectivos de longo prazo ${ }^{(10,44)}$.

O estudo de tecidos parafinados tem algumas vantagens; o material possui alta qualidade morfológica, apresenta-se em grande quantidade, é de fácil acesso e permite identificação de lesões precursoras ${ }^{(3)}$. Em alguns casos, como de doenças raras, é o último recurso disponível para a análise genética ${ }^{(34)}$. A extração para amplificação do DNA, a partir de blocos de parafina, apresenta alguns pontos críticos, que podem influenciar no insucesso da amplificação. Grau de fragmentação do DNA, efeito do fixador, tempo de fixação e temperatura utilizada no processamento do material são exemplos de fatores que podem influenciar na amplificação dessas amostras de DNA ${ }^{(20-22)}$. 


\section{Prefixação}

\section{Tempo de prefixação}

A prefixação é o tempo passado entre a coleta ou excisão cirúrgica do espécime e o início do processo de fixação ${ }^{(40)}$. Uma das condições básicas para boa fixação e, consequentemente, preservação do material é que o fixador seja aplicado ao espécime tão cedo quanto possível, após a coleta cirúrgica ou post-mortem ${ }^{(15)}$.

Boa parte dos tecidos é removida cirurgicamente. Nas cirurgias, os tecidos podem ser expostos à hipóxia por algum período de tempo; caso a interrupção da circulação seja continuada, instala-se estado de anóxia tecidual. O processo de anóxia causa alterações locais de $\mathrm{pH}$ e pode levar ao aumento de fatores de transcrição de alguns genes relacionados com a morte celular. As alterações bioquímicas começam a ocorrer, em média, em 10 minutos após iniciado o quadro de anóxia, embora esse tempo varie conforme a natureza e o metabolismo do tecido. Portanto, o tempo de prefixação deve ser reduzido a segundos, a fim de minimizar a degradação de RNA e proteínas, especialmente nos tecidos com altos níveis de RNAses e proteases, como pâncreas, vesícula biliar, pele e intestino ${ }^{(40)}$.

Alguns cuidados básicos devem ser tomados assim que a peça anatômica deixa o centro cirúrgico e chega ao setor de patologia, por exemplo:

- o volume do fixador deve ser cerca de 10 vezes o volume do tecido; caso contrário, dependendo das dimensões do material, este deverá ser recortado em fatias suficientemente delgadas, a fim de que 0 volume do fixador em relação ao volume da peça atinja os padrões ideais;

- excesso de sangue e muco na superfície dos órgãos forma um filme protetor, impedindo a penetração adequada do fixador nos tecidos;

- o processo autolítico post-mortem é mais rápido nos órgãos com maiores quantidades de enzimas, como fígado, rins e pâncreas, e mais lento nos tecidos de sustentação, como o conjuntivo;

- espécimes do tubo digestivo - deve-se proceder ao exame macroscópico rapidamente, com coleta de amostras para fixação imediata, pois a membrana mucosa digestiva é bastante suscetível à autólise ou a alterações post-mortem;

- órgãos ou tecidos encapsulados devem ser abertos para que se tenha boa penetração do fixador ${ }^{(2,15)}$.
O tempo de fixação e o fixador utilizado influenciam na preservação de macromoléculas, como DNA, RNA e proteínas, o que torna esse processo importante para a obtenção dos resultados a partir das técnicas de imuno-histoquímica e biologia molecular ${ }^{(5)}$.

\section{Fixação}

\section{Descalcificação e fixação}

Para que se possa examinar histologicamente o tecido ósseo ou calcificado, antes de realizar a microtomia deve-se fazer a descalcificação, método que consiste na remoção do cálcio tecidual, sem alterações na estrutura morfocelular. Várias substâncias podem ser empregadas como descalcificadores (todas de natureza ácida): ácidos nítrico, fórmico, clorídrico, acético, pícrico, sulfúrico, tricloroacético e sulfossalicílico. Fixa-se o tecido em formalina por 12 ou 24 horas antes do processo de descalcificação. Após esse passo, coloca-se o fragmento de tecido no líquido descalcificador, em volume 100 vezes maior ao da peça, trocando o líquido diariamente até que o tecido amoleça. $\mathrm{O}$ ponto adequado de descalcificação é atingido quando é possível transpassar o tecido com um alfinete sem que haja resistência ou dureza, indicando que o tecido está pronto para sofrer os demais procedimentos histológicos ${ }^{(42)}$.

As substâncias fixadoras têm por finalidades básicas evitar alterações da constituição química das células, fixar proteínas e inativar enzimas proteolíticas, responsáveis pelo fenômeno de autólise ${ }^{(18,42)}$. Os mecanismos de ação dos fixadores podem ser amplamente categorizados como desidratantes, caloríferos, de ligação cruzada e acidificantes ou ainda como a combinações destes ${ }^{(40)}$.

A fixação depende de processos físico-químicos em que os constituintes químicos dos tecidos, principalmente as proteínas, são coagulados ou precipitados in situ. Uma fixação bem sucedida dependerá do conhecimento preciso das propriedades físicas e químicas dos constituintes a serem preservados e suas interações com substâncias fixadoras ${ }^{(15,19)}$.

A maioria dos bons fixadores é constituída por duas ou mais substâncias, a fim de que, ao serem combinadas, corrijam os defeitos uma em relação à outra ${ }^{(2,4,42)}$. Alguns tipos de fixador, que contêm soluções como mercúrio e ácidos descalcificantes, podem não ser compatíveis com testes de biologia molecular, pois interferem de alguma forma em seus resultados ${ }^{(16)}$.

O líquido de Bouin, que contém ácido pícrico e ácido acético glacial, podendo ou não conter formalina, é um 
fixador com característica descalcificante e é muito utilizado para o processamento de amostras de medula óssea. Após a fixação, é recomendada a remoção do ácido pícrico dos tecidos, antes de dar continuidade aos demais procedimentos histológicos. Resíduos desse ácido podem favorecer a deterioração da peça com o passar do tempo ${ }^{(34,41)}$.

$\mathrm{O}$ pH das soluções fixadoras é um dos fatores mais importantes a serem considerados no momento da fixação de um material. A concentração iônica desequilibrada faz que íons livres atuem destruindo os tecidos; a neutralização dos íons livres evita a oxidação dos tecidos. Os tampões estabilizam as modificações de $\mathrm{pH}$ que acompanham a morte celular à medida que o fixador penetra nos tecidos ${ }^{(2,4)}$.

\section{Aldeído fórmico e sua interação com proteína e DNA}

Um fixador balanceado que se adéqua praticamente a todas as necessidades para histologia e patologia de rotina é o aldeído fórmico $10 \%$, que é uma solução a $10 \%(\mathrm{v} / \mathrm{v})$ de formalina (solução aquosa saturada a $40 \%$ p/v de aldeído fórmico) ${ }^{(4)}$. O tecido fixado em formol pode permanecer por mais de 10 anos sem significativas modificações de sua estrutura, podendo ser posteriormente refixado em quase todos os outros fixadores ${ }^{(15,42)}$.

$\mathrm{O}$ aldeído fórmico tem alguns inconvenientes, como formação de pigmentos de formol e de ácido fórmico. Quando exposto à luz, o formol se transforma em ácido fórmico, provocando redução do $\mathrm{pH}$ do material. Esse processo é o ponto de partida para as demais alterações celulares desfavoráveis às técnicas de biologia molecu$\operatorname{lar}^{(2,12,15)}$. A fixação em formol e a emblocagem em parafina são adequadas a muitos métodos histoquímicos qualitativos e quantitativos. São igualmente adequadas ao campo da imuno-histoquímica, com métodos e reações padronizadas e de uso rotineiro.

A reação do aldeído fórmico com a proteína tem como base alguns grupamentos químicos, como amina, amida e grupos guanidil(25). O formaldeído reage com a amina ou grupos triol de aminoácidos e forma derivados de metilol $\left(\mathrm{R}-\mathrm{NH}_{2}+\mathrm{CH}_{2} \mathrm{OH} \rightarrow \mathrm{R}-\mathrm{NH}-\mathrm{CH}_{2} \mathrm{OH}\right.$ ). Essa ligação aumenta a reatividade dos componentes metilol, favorecendo a condensação dos grupos metilol com amida ou outros grupos que produzem pontes de metileno, que fazem ligação cruzada com cadeias polipeptídicas ${ }^{(12,25,30)}$.

No caso da amina primária, o grupo metilol sofre parcialmente uma condensação, convertendo-se em imina ou em base de Schiff. Subsequentemente, uma imina ou base de Schiff pode fazer ligação cruzada com resíduos de glutamina, asparagina, triptofano, histidina, arginina, lisina, cisteína e tirosina ${ }^{(12,25)}$. Aminoácidos aromáticos permitem a ligação cruzada entre o aminometilol e os grupos fenol, inol ou imidazol. A ligação de metilação entre átomos de nitrogênio e carbono são muito estáveis e resistentes a hidrólises ácidas( ${ }^{(30)}$.

As proteínas sofrem alteração estrutural em razão das reações de ligação cruzada. Devido às suas sequências variadas, os peptídeos sofrem variedade de modificações químicas após o tratamento com formaldeído, as quais podem ser divididas em três tipos: grupos metilol, base de Schiff e ligação de metilação. A formação de metilol e bases de Schiff são reversíveis. A maioria das modificações importantes nos peptídeos (proteínas), induzidas pelo formaldeído, ocorre devido à formação de ligações de metilação estáveis(25).

Estudos químicos feitos entre formaldeído e ácido nucleico demonstraram que a reação básica entre eles é similar à observada na interação entre formol e proteína. O processo de formalização começa com a desnaturação: quebra de ligações de ponte de hidrogênio e desligamento de bases, em regiões ricas em adenina e timina (AT) da dupla fita de DNA, criando novas interações químicas ${ }^{(40)}$.

Segundo Srinivasan et al. ${ }^{(40)}$, o formol tem quatro formas de interação com o DNA. A primeira é uma reação de adição; o formaldeído é acrescentado à base do ácido nucleico para formar um grupo hidroximetil $\left(-\mathrm{CH}_{2} \mathrm{OH}\right)$, que é um metilol. $\mathrm{O}$ segundo é um lento ataque eletrofílico do N-metilol a uma base amino para formar uma ponte de metilação entre os dois grupos de amino. O terceiro é o tratamento com formaldeído que pode gerar sítios de apurinas e apirimidinas (AP) por hidrólise da ligação $\mathrm{N}$-glicosídica, deixando resíduos livres de pirimidina e purina. Sítios AP têm aumento dos íons carboxilas cíclicos instáveis, que se hidrolisam rapidamente para produzir 2-deoxi-D-ribose. O quarto e último é o formaldeído que pode também causar lenta hidrólise da ligação fosfodiéster, principalmente as ligações curtas de polideoxiribose com pirimidina intacta.

A fixação com formaldeído resulta no enovelamento de proteínas nucleares, na formação de ligações entre proteínas e DNA e na fragmentação do DNA. Contudo, a usual tentativa de extração de DNA de tecidos fixados em formol para estudos de biologia molecular tem se apresentado uma opção variavelmente bem-sucedida ${ }^{(24,28,40)}$. 


\section{Pós-fixação}

\section{Protocolo básico}

A extração do DNA de blocos de parafina fixados em formol foi realizada pela primeira vez em 1985 por Goelz et al., utilizando como principais reagentes a proteinase $\mathrm{K}$ e o dodecilsulfato de sódio (SDS) ${ }^{(37)}$. Na literatura existem vários protocolos com a finalidade de extração de DNA de material parafinado, cada um utilizando substâncias e estratégias diferentes. O DNA obtido desses materiais é importante para a realização de estudos na área da biologia molecular ${ }^{(24,38)}$.

O protocolo mais frequentemente utilizado para a extração de DNA de tecidos fixados e emblocados em parafina compreende a desparafinização da amostra por calor ou solventes, tratamento por digestão com enzimas proteolíticas sucedido, ou não, por purificação com solventes orgânicos e precipitação com etanol(3,24,26).

Vários são os passos que podem ser modificados para a obtenção de métodos mais rápidos e práticos para a extração de DNA amplificável de materiais emblocados em parafina. Essas variações vão desde a forma de obtenção dos cortes e o modo de coleta (cortes, biópsia de bloco etc.) até a espessura em micrômetros dos cortes. A desparafinização, além de opcional, se for feita, pode ser realizada por meio de calor ou lavagens com solventes como o xilol(3). Os componentes principais do tampão de digestão (Tris- $\mathrm{HCl}$, ácido etilenodiaminotetracético [EDTA], cloreto de sódio [ $\mathrm{NaCl}]$, detergente e proteinase $\mathrm{K}$ ) podem variar de concentração e tempo de utilização e podem ser substituídos por substância homóloga ${ }^{(13)}$.

\section{Desparafinização}

Os cortes de material parafinado devem ser desparafinizados para a obtenção de uma extração de DNA eficiente, segundo a maioria dos autores consultados. Assim, torna-se necessário retirar a parafina do corte e, em seguida, hidratar o tecido. Contudo, sendo a parafina insolúvel em água e pouco solúvel no álcool, para que os cortes possam ser desparafinizados é necessário que previamente sejam penetrados por um solvente da parafina, como xilol e benzol, para depois serem reidratados ${ }^{(3,4,42)}$.

A técnica mais comum para a remoção da parafina baseia-se no uso de xilol em concentrações crescentes (ou outro solvente similar) e posteriores banhos com etanol. Existem métodos alternativos, como a remoção direta por meio do uso de banho-maria para derreter a parafina, ou mesmo a não desparafinização das amostras(13, 17).
A retirada da parafina pode ser realizada mediante calor e/ou lavagens com solventes como o xilol. Existem protocolos em que há a obtenção por um pré-tratamento com calor, imerso em solvente ou não antes da centrifugação com xilol. Os passos de retirada da parafina com solvente orgânico podem variar de autor para autor. O número e o tempo dos banhos de xilol, assim como o processo de centrifugação, variam muito de acordo com a preferência do pesquisador ${ }^{(13,26,32,43)}$.

\section{Digestão}

Na primeira fase da técnica de extração do DNA, objetiva-se a ruptura ou lise das membranas celulares com a finalidade de liberar os componentes citoplasmáticos e/ou nucleares intracelulares. As metodologias mais comumente utilizadas para essa finalidade são fervura, digestão enzimática (proteinase $\mathrm{K}$, lisozima), ruptura mecânica (homogeneização), ondas sonoras (sonicação), detergentes (SDS, Triton X-100), detergentes não iônicos (Tween 20, Laureth 12), chaotropes, (isotiocianato de guanidina, iodeto de sódio) e soluções (salina hipotônica) na dependência do tipo de amostra ou célula $(14,16,24)$.

Frequentemente, as células animais podem requerer a utilização de duas ou mais substâncias com a finalidade de romper a matriz tecidual e assim melhorar a disponibilidade das células para a substância de lise. A função do tampão de lise, além de destruir membranas plasmáticas, é manter o $\mathrm{pH}$ e quelar metais que, porventura, possam ativar endonucleases. Além das diferentes substâncias, o tempo em que as células ficam submetidas ao contato das substâncias e suas concentrações influenciam na qualidade e na quantidade final de DNA extraído(7, 24).

A partir do material hidratado inicia-se a digestão dos componentes celulares e a extração propriamente dita do DNA. Existem na literatura vários protocolos que descrevem o método de digestão celular. Há autores que relatam a utilização de fervura, acompanhada ou não de solução de lise, e/ou digestão com proteinase $\mathrm{K}$ e ainda a utilização desses métodos associados a diferentes tampões ${ }^{(27,38,43)}$. Outros descrevem a utilização do detergente Triton X-100 e do tiocianato de guanidina para verificar a efetividade dessas substâncias na ruptura ou lise das membranas celulares ${ }^{(14,24)}$. A utilização do detergente SDS, combinado com a proteinase $K$, que realiza a digestão enzimática, apresenta como resultado eficiente extração de $\mathrm{DNA}^{(6,14)}$. Métodos com base na digestão enzimática (proteinase $\mathrm{K}$ ), independentemente do método de extração do DNA genômico, resultam em materiais com quantidade e pureza 
satisfatórias para amplificação do DNA com a utilização da técnica de PCR. O tempo de digestão por proteína K (que pode variar de 1 hora a cinco dias) e a concentração desta no tampão de digestão variam de autor para autor ${ }^{(3,16,24)}$.

\section{Purificação}

Após a obtenção do lisado contendo proteína, ácidos nucleicos (DNA/RNA) e lipídios, existe a necessidade de separar os ácidos nucleicos das outras moléculas ${ }^{(24)}$. Está descrito na literatura variado número de diferentes métodos de recuperação e purificação de ácidos nucleicos, procedimentos seguintes aos pré-tratamentos de desparafinização e digestão. Esses protocolos apresentam algumas diferenças de acordo com o alvo em foco (DNA ou RNA) ou conforme a composição química do fixador ${ }^{(13,16)}$.

A técnica com fenol-clorofórmio é a metodologia mais comumente utilizada. Essa metodologia apresenta-se, com frequência, como método de purificação de alta eficiência para extração de DNA proveniente de materiais emblocados em parafina. O princípio dessa separação é a diferença de solubilidade de ácidos nucleicos, proteínas e lipídios nesses solventes orgânicos, de forma que, após a realização dessa separação, se obtém uma fase aquosa, em que se encontra o ácido nucleico ${ }^{(24,32)}$. O fenol-clorofórmio utilizado após o rompimento da membrana celular auxilia na desnaturação das proteínas, que são removidas pelas subsequentes centrifugações e lavagens ${ }^{(7,32)}$.

Aparentemente, o método de purificação com fenolclorofórmio tem resultado na recuperação e purificação satisfatórias em comparação com outras técnicas ${ }^{(6,8,24)}$. No estudo de Mesquita et al. ${ }^{(24)}$, foi feita uma comparação de três métodos de purificação utilizando-se fenol-clorofórmio com proteinase $\mathrm{K}$, sílica sem proteinase $\mathrm{K}$ e sílica com proteinase K. Fenol-clorofórmio com técnica de sílica com a presença de proteinase $\mathrm{K}$ mostrou ser eficiente na purificação, resultando em um material de ótima qualidade para PCR. Riveiro et al. ${ }^{(32)}$ afirmam em seu trabalho que a metodologia de fenol-clorofórmio é um excelente método para extração de DNA de tecidos emblocados em parafina, assim como o melhor método avaliado para extração de espécimes de células bucais.

O fato de os solventes orgânicos (fenol e clorofórmio) serem reagentes tóxicos traz problemas em sua manipulação. Além disso, o método necessita de grande número de fases no processo laboratorial. Esse fato fez que, atualmente, pesquisadores buscassem alternativas para a extração de DNA, tanto em materiais parafinados como em amostras fora dessas condições $(1,32)$.
Uma alternativa é o protocolo de salting-out, que utiliza uma solução de $\mathrm{NaCl}$, ou raramente acetato de amônia para precipitar as proteínas e tradicionalmente acetato de amônia para precipitar ácido nucleico. O método de salting-out, além de necessitar de menos passos laboratoriais, não apresenta tanta toxicidade quando comparado com a do protocolo que utiliza fenol-clorofórmio. Esse método é amplamente utilizado na extração de DNA de sangue, amostras citológicas e materiais sólidos e o mesmo obteve resultados satisfatórios de purificação de ácidos nucleicos de amostras fixadas em formol e emblocados em parafina ${ }^{(32,33)}$.

Outro método que não utiliza solvente orgânico e, portanto, não apresenta toxicidade é o método de purificação com Chelex-100 associado à proteinase K. O Chelex-100 é uma solução quelante, que preferencialmente quela íons metálicos polivalentes, prevenindo a degradação do DNA. A técnica de Chelex-100 pode ser empregada, com sucesso, em amostras com poucas células, vários tipos de matérias forenses e tecidos emblocados em parafina ${ }^{(35,38)}$.

Existem disponíveis no mercado muitos kits para extração de DNA, tanto de materiais parafinados como para outros tipos de materiais. Eles são utilizados por muitos autores na tentativa de obtenção de amostras de ácidos nucleicos de boa qualidade, provenientes de matérias fixados em formol e emblocados em parafina ${ }^{(8,11,27-29,34,39)}$.

O kit comercial da Qiagen (QIAamp DNA minikit) é relatado em muitos trabalhos científicos que têm como objetivo a obtenção de DNA de amostras emblocadas em parafina. Em muitos desses trabalhos, o kit comercial apresentou DNA de boa qualidade e resultados satisfatórios de amplificação $0^{(6,8,13,29,38,39)}$.

Estes são outros kits que em trabalhos científicos mostram ser eficientes na extração DNA de matérias parafinadas: Wizard Genomic DNA Purifications Kit (Promega), Kit GFXtm Genomic Blood DNA Purification, Quick-Gene DNA Tissue Kit S (Fujifilm Life Science), QIAquick Gel Extraction Kit e Kit Glass Max (Gibco BRL, USA) ${ }^{(11,27,34,39) .}$

Uma cuidadosa comparação entre métodos comerciais e in-house em espécimes arquivados foi demonstrada no trabalho de Okello et al. ${ }^{(28)}$. Nessa pesquisa, foi apresentada comparação qualitativa e quantitativa do DNA por meio de sete kits comerciais disponíveis, dos quais dois divididos em duas extrações distintas, e um método in-house (fenolclorofórmio). Os autores demonstram que os kits WaxFree Paraffin Sample RNA Preparation e RecoverAll Total Nucleic Acid Isotion Kit-DNA juntamente com a técnica in-house são os métodos preferenciais para a recuperação de DNA amplificável(28). 


\section{Conclusão}

A qualidade de um produto está diretamente relacionada com a qualidade dos processos a que é submetido(9). Segundo Corrêa a Chaves-Neto, o produto final é símbolo de qualidade quando, durante cada um dos vários estágios do processo, ocorre a menor variabilidade possível( ${ }^{(9)}$. A compreensão desse conceito mostra a importância do entendimento das etapas de prefixação, fixação e pós-fixação e a redução da variabilidade dos processos envolvida em cada etapa. Portanto, identificar as causas da variabilidade e eliminá-las do processo é fundamental para os resultados finais.

As causas naturais de variação são consequências do acúmulo de várias causas muito pequenas, mas inevitáveis. As causas não naturais de variabilidade podem ter como fontes mão de obra, máquinas, meio ambiente, matériaprima, método de trabalho e meios de medição. As razões da variabilidade não natural são aspectos que devem ser controlados nas etapas de prefixação, fixação e pós-fixação, a fim de se obter um material com mais qualidade. Muitos aspectos que causam efeitos negativos para a qualidade de macromoléculas não podem ser alterados devido a sua essencialidade, como, por exemplo, o uso de descalcificadores e fixadores, mas suas interferências podem ser minimizadas quando compreendidas.

Assim, um estudo prévio de todo o sistema, desde o tipo de tecido até a escolha do método de extração e purificação, trará informações de possíveis fatores adversos que podem vir a influenciar na qualidade das macromoléculas. Caberá ao pesquisador interpretar e tentar solucionar ou minimizar o problema.

\section{Referências}

1. ABRÃO, M. G. et al. Padronização da técnica de extração de DNA de células de mucosa oral com $\mathrm{NaCl}$ : aplicação no estudo do gene PROP1. Arq Bras Endocrinol Metab, v. 49 , n. 6, p. 978-82, 2005.

2. ALVES, A. Análises histopatológicas: porque demoram os resultados. In: CONGRESSO DE CIÊNCIAS VETERINÁRIAS, 2002. p. 239-47.

3. BAREA, J. A.; PARDINI, M. I. M. C.; GUSHIKEN, T. Extração de DNA de materiais de arquivo e fontes escassas: revisão e apontamentos sobre as possíveis aplicações. NewsLab, v. 63, p. 96-114, 2004.

4. BECAK, W. Métodos de estudo. In: BECAK, W. Técnica de citologia e histologia. Rio de Janeiro: Livros Técnicos, 1976. p. 22-38.

5. BEN-EZRA, J. et al. Effect of fixation on the amplification of nucleic acids from paraffin-embedded material by the polymerase chain reaction. JHC, v. 39, n. 3 , p. 351-4, 1991

6. CAO, W. et al. Comparison of methods for DNA extraction from paraffin-embedded tissues and buccal cells. Cancer Detection and Prevention, v. 27, p. 397-404, 2003.

7. CARNEIRO, N. P. et al. Extração de DNA de Spiroplasma kunkelii whitcomb cultivado in vitro. Circular Técnico, v. 34, p. 61-5, 2003.

8. COOMBS, N. J.; GOUGH, A. C.; PRIMROSE, J. N. Optimisation of DNA and RNA extraction from archival formalin-fixed tissue. Nucleic Acids Research, v. 27, n. 16, p. e12, 1999.

9. CORREAA, J. M.; CHAVES-NETO, A. Estudo do controle e análise da capacidade do processo de produção de água potável. In: XLI SBPO - Pesquisa Operacional na Gestão do Conhecimento, 2009. p. 1414-24.

10. DEVRIES, S. et al. Array-based comparative genomic hybridization from formalin-fixed, paraffin-embedded breast tumors. J Mol Diagn, v. 7, p. 65-71, 2005.
11. FERNANDES, J. V. et al. Comparação de três protocolos de extração de DNA a partir de tecido fixado em formol e incluído em parafina. J Bras Patol Med Lab, v. 40, n. 3, p. 141-6, 2004.

12. FOX, C. H. et al. Formaldehyde fixation. JHC, v. 33, n. 8 , p. 845-53, 1985.

13. GILBERT, M. T. P. et al. The isolation of nucleic acids from fixed, paraffin-embedded tissues-which methods are useful when? PLOS ONE, v. 2, n. 6, p. e537, 2007.

14. GOLDENBERGER, D. et al. A simples "universal" DNA extraction procedure using SDS and proteinase $\mathrm{K}$ is compatible with direct PCR. PCR Methods Appl, v. 4, p. 368-70, 1995

15. GRIMALDI FILHO, G. Fixação. In: GRIMALDI FILHO, G. Técnica histológica. 2. ed. Rio de Janeiro: Instituto Oswaldo Cruz, 1981. p. 10-39.

16. HUNT, J. L. Molecular pathology in anatomic pathology practice: a review of basic principles. Arch Pathol Lab Med, v. 132, p. 248-60, 2008.

17. ISHIKAWA, C. C. et al. Imunofenotipagem e rearranjo gênico em doenças pulmonares linfocíticas e linfoproliferativas. J Bras Pneumol, v. 33, n. 6, p. 625-34, 2007.

18. JUNQUEIRA, L. C.; CARNEIRO, J. Histology \& its methods of study. In: JUNQUEIRA, L. C.; CARNEIRO, J. Basic histology. 11. ed. New York: McGraw-Hill, 2005. p. 1-18. E-book.

19. KINGSBURY, B. F.; JOHANNSEN, O. A. Fixation. In: KINGSBURY, B. F.; JOHANNSEN, O. A. Histological technique: a guide for use in a laboratory course in histology. 2. ed. New York: Kingsbury Press, 1927. p. 1-6. E-book.

20. KULLMANN, F. et al. A comparison of methods for DNA extraction from paraffin-embedded tissue for microsatellite instability analysis by PCR. Acta Biotech, v. 18, n. 1, p. 77-83, 1998.

21. LEHMANN, U.; KREIPE, H. Real-time PCR analysis of DNA and RNA extracted from formalin-fixed and 
paraffin-embedded biopsies. Methods, v. 25, n. 4, p. 409-18, 2001.

22. LIU, L.; JOHNSON, R. M.; TRAWEEK, S. T. Rearrangement of the BCL-2 gene in follicular lymphoma. Detection by PCR in both fresh and fixed tissue samples. Diagn $\mathrm{Mol}$ Pathol, v. 2, n. 4, p. 241-7, 1993.

23. MACHUCA, T. N. et al. Gliosarcoma: report of four cases with immunohistochemical findings. Arq Neuropsiquiatr, v. 62, n. 3-A, p. 608-12, 2004.

24. MESQUITA, R. A. et al. Avaliação de três métodos de extração de DNA de material parafinado para amplificação de DNA genômico pela técnica da PCR. Pesq Odontol Bras, v. 15, n. 4, p. 314-9, 2001

25. METZ, B. et al. Identification of formaldehyde-induced modifications in proteins. JBC, v. 279 , n. 8, p. 6235-43, 2004.

26. MIRSHAHABI, H. et al. Different DNA extraction methods for paraffin-embedded pathological samples. IJP, v. 2, n. 4, p. 159-64, 2007.

27. NASCIMENTO, E. M. et al. Protocolo da extração de DNA de material parafinado para análise de microssatélites em leiomioma. J Bras Patol Med Lab, v. 39, n. 3, p. 253-5, 2003.

28. OKELLO, J. B. A. et al. Comparison of methods in the recovery of nucleic acids from archival formalin-fixed paraffin-embedded autopsy tissues. Analytical Biochemistry, v. 400, p. 110-7, 2010.

29. PRINCE, M. E. et al. Tissue-preserving approach to extracting DNA from paraffin-embedded specimens using tissue microarray technology. Head \& Neck, v. 29 , n. 5, p. 465-71, 2007.

30. PUCHTLER, H.; MEIOAN, S. N. On the chemistry of formaldehyde fixation and its effects on immunohistochemical reactions. Histochemistry, v. 82, p. 201-4, 1985.

31. RIBEIRO-SILVA, A.; GARCIA, S. B. Estudo comparativo de três diferentes procedimentos para extração e RNA a partir e amostras fixadas em formalina e embebidas em parafina. J Bras Patol Med Lab, v. 44, n. 2, p. 123-30, 2008.

32. RIVERO, E. R. C. et al. Simple salting-out method for DNA extraction from formalin-fixed paraffin-embedded tissues. Pathology: Research and Practice, v. 202, p. 523-9, 2006.

33. SANTOS, M. C. L. G.; SAITO, C. P. B.; LINE, S. R. P. Extraction of genomic DNA from paraffin-embedded tissue sections of human fetuses fixed and stored in formalin for long periods. Pathology: Research and Practice, v. 204, p. 633-6, 2008. doi: 10.1016/j. prp.2008.04.005,A.
34. SANTOS, S. et al. An efficient protocol for genomic DNA extraction from formalin-fixed paraffinembedded tissues. Res Vet Sci, 2008. doi: 10.1016/j. rvsc.2008.08.007,B.

35. SEPP, R. et al. Rapid techniques for DNA extraction from routinely processed archival tissue for use in PCR. Clin Pathol, v. 47, p. 318-23, 1994.

36. SEUÁNEZ, H. N. et al. Métodos moleculares de diagnóstico. In: FERREIRA, C. G.; ROCHA, J. C. Oncologia molecular. São Paulo: Atheneu, 2004. p. 13-27.

37. SHIN, S. R. et al. DNA extraction from archival formalin-fixed, paraffin-embedded tissue sections based on the antigen retrieval principle: heating under the influence of $\mathrm{pH} . \mathrm{JHC}$, v. 50, n. 8, p. 1005-11, 2002.

38. SIMONATO, L. E. et al. Avaliação de dois métodos de extração de DNA de material parafinado para amplificação em PCR. J Bras Patol Med Lab, v. 43, n. 2, p. 121-7, 2007.

39. SJOHOLM, M. I. L. et al. Comparison of archival plasma and formalin-fixed paraffin-embedded tissue for genotyping in hepatocellular carcinoma. Cancer Epidemiol Biomarkers Prev, v. 14, n. 1, p. 251-5, 2005.

40. SRINIVASAN, M.; SEDMAK, D.; JEWELL, S. Effect of fixatives and tissue processing on the content and integrity of nucleic acids. AJP, v. 161, n. 6, p. 1961-71, 2002.

41. TIMM, L. L. Técnicas rotineiras de preparação e análise de lâminas histológicas. Caderno La Salle XI, v. 2, n. 1, p. 231-9, 2005.

42. TOLOSA, E. M. C. et al. Técnica histológica. In: TOLOSA, E. M. C. et al. Manual de técnicas para histologia: normal e patológica. 2. ed. Rio de Janeiro: Manole, 2003. p. 19-85.

43. VILANOVA-COSTA, C. A. S. T.; NÓBREGA, J. B.; CRUZ, R. S. A. D. Extração e purificação de DNA em material biológico parafinado. Goiânia, Estudos, v. 35, n. 1/2, p. 143-52, 2008.

44. VINCEK, V. et al. A tissue fixative that protects macromolecules (DNA, RNA, and protein) and histomorphology in clinical samples. Laboratory Investigation, v. 83, n. 10, p. 1427- 35, 2003.

45. WAJNER, M.; VARGAS, C. R. Diagnóstico genético-molecular aplicado à medicina humana. In: MARQUES, E. K. Diagnóstico genético-molecular. Canoas: Ed. ULBRA, 2000. p. 71-126.

46. WATSON, P. H.; SNELL, L.; PARISIEN, M. The NCICmanitoba breast tumor bank: a resource for applied cancer research. Can Med Assoc J, v. 155, n. 3, p. 281-3, 1996. 